\title{
Human Behavior on the Development of Group Technology: A Study in Sri Lankan Apparel Industry
}

\author{
A.K.D.N. Dilshani ${ }^{1}$ \& U.L. Herat ${ }^{2}$ \\ Department of Business Management \\ Faculty of Business Studies \& Finance \\ Wayamba University of Sri Lanka \\ Kuliyapitiya \\ SRI LANKA \\ dilshani@wyb.ac.lk ${ }^{1}$, umangi@wyb.ac.lk ${ }^{2}$
}

\begin{abstract}
Greater attention was paid to the increasing need of organizations for alternate process solutions to integrate the efficiency of product flow layouts with the flexibility of functional layouts. The solution, at least for some organizations, is group technology (GT). Much GT studies focused on the technical concerns involved in transforming functionally segregated operations into integrated multifunctional cells. However, it is proposed that a complementary connection between technical and human behaviour is required to ensure the optimization of GT implementations. In that regard, the present research was primarily conducted to study the effect of human behaviour on the implementation of the GT, especially referring to the apparel industry in Sri Lanka, where the GT was introduced as a key strategy for process improvement initiatives to reduce the burning issue of longer lead time. In addition, the study aims to explore the key factors for implementing the GT and the perceived benefits that can be obtained from the implementation of GT. A selection of 70 executives from the sewing departments of garment manufacturing organizations where the GT concept was applied, was chosen on the basis of a judgmental sampling technique. The questionnaire was the primary research instrument. Findings have shown that high inventory storage, high lead time, quality problems and, as well as dissatisfaction among staff, are the serious manufacturing issues that contributed to the implementation of GT. Furthermore, the potential advantages of using GT include improved productivity of employees, skills of workers, flexibility, on time delivery, and product quality, while decreasing lead time, inventory level, set up time, throughput time, and production and quality control cost. Employee resistance to change has been shown to have the greatest detrimental effect on the implementation of the GT.
\end{abstract}

Keywords: Group Technology (GT), Human Behaviour, Apparel Industry, Sri Lanka

\section{INTRODUCTION}

Many companies, large or small, face serious challenges from a dynamic and complex global economy, challenges that have put in question the effectiveness of traditional management methods. Some of these 
challenges include growing demand from customers for better quality products and services at lower prices, competitive pressures, keeping up with technological developments, and supplier pressures. To overcome these challenges and become more efficient, organizations will have to create alternatives to hierarchies, change the way decisions are made, change the way of doing business, redefine jobs, and make the necessary structural changes (Lussier \& Achua, 2003). One popular approach to structural changes to meet these challenges has been the implementation of Group Technology (GT) in the organizations.

GT involves the redesign of a functionally organized small batch manufacturing facility (i.e., a job shop) into a cellular layout in which dissimilar but sequentially related machines are relocated in physical proximity to one another and dedicated to the manufacture of a specific family of component parts (Pullen, 1976; Wemmerlov \& Hyer 1989). GT offers an opportunity to combine the efficiency of product flow layouts with the flexibility of functional layouts (Anbumalar \& Sekar, 2015). In this type of layout, groups dissimilar machines into work cells to work on products that have similar processing requirements. GT reduces the part movements since the products are processed in a single cell.

It also reduces the scheduling complexities. This layout is designed to obtain much of the efficiency of a product layout without sacrificing flexibility. Using many cells, with facility with such a layout can produce a variety of items. GT can be much more flexible than product layouts and much more efficient than process layouts. Variety of items within a certain range can be efficiently produced using a cellular layout (Perera, 2009).

Since the late-1970s, the Sri Lankan apparel industry underwent rapid growth and continues to be the largest manufacturing market. The role played by the apparel industry in Sri Lanka is significant in many respects. It is now becoming one of the strongest manufacturing sub-sectors, the largest export contribution, foreign exchange earnings, the Gross Domestic Product (GDP) and the development of job opportunities occupy a prominent role in this regard.

Considering the output of Sri Lanka's industrial sector, the most important of these is apparel production. Similarly, the apparel industry is currently the leading export-oriented industry in Sri Lanka and as well as it has provided vast quantities of direct and indirect jobs to nearly 600,000 workers. But the industry is operated in such an environment that they are the victim of low labour productivity, high WIP, low labor utilization and higher manufacturing cost, excessive manufacturing lead times. The most important task for the industry is to reduce the lead time of garment manufacturing (Kumar, Anbumalar, Bala Ganesh and Mayandy, 2014).

Garment manufacturing in
comparison to most other
manufacturing industries use light
weight machineries which are easily
movable during a changeover.
Therefore, the present practice is to 
rearrange the garment manufacturing line when a garment style needs to be changed. The same machine arrangement may prevail for several years for large order quantities or it may last only few hours as the order quantities can be as small. As the fashion is changing rapidly, today's trend of the garment industry is to move towards small order quantities. Hence the garment manufacturing lines should react fast for rapid changeover (Lanarolle and Ratnayake, 2014). GT is considered and adopted by most garment manufacturing organizations as core strategy in process improvement initiatives.

While there is no doubt about the increasing popularity of GT, companies at large fall short of achieving benefits that were perceived as being important to GT adoption (Fraser et al). However according to Udo \& Ehie (1996) only half of those companies adopting GT ever attain successful implementation. Study also revealed that a considerable gap exists between the organizations' expectations and their actual achievements of GT benefits.

It is argued that a contributing reason why the full benefits of GT have not been achieved is due to the fact that the research literature on cellular manufacturing over the last 15 years has to an overwhelming degree focused on the development of procedures to solve the cell formation problem (machine order/layout, family part grouping, work flow sequence) (Wemmerlov \& Johnson, 2000). To a large degree this is also true in practice. It is now accepted that a number of fundamental social changes do occur when companies convert from functional manufacturing layouts to manufacturing cells. These social changes along with the required technical modifications will require careful attention by practitioners because of their potential impact on employee attitudes, motivation, and retention, and therefore the overall success of GT implementation (Fraser et al).

Most research on GT has focused on the technical issues involved in converting functionally segregated operations into integrated multifunctional cells. Examples of these technical issues include classification methods, physical arrangements, methods for reducing set-up time, and design of work flow sequence. By comparison, research on the human or social side of GT has been notably lacking (Huber \& Brown, 1991). It is now clear that not only the technical factors but also human factors play significant role in the success of GT.

As the garment industry is more people involved process it is critical to obtain the positive commitment of people in the implementation of any technique (Lanarolle and Ratnayake, 2014). Accordingly, this study was primarily conducted to study the impact of human behavior on the implementation of GT specially referring to the apparel industry in Sri Lanka. Moreover, study tries to investigate the main reasons for implementing GT and the perceived benefits that can be gained from implementing GT. 


\subsection{Research Problem}

GT is a well-known strategy in removing many of the inefficiencies associated with functional batch-type manufacturing environments. It is widely accepted that the successful implementation of GT will bring much benefits such as reducing delivery lead times, set up time, lot size, work-inprocess inventory and defects, while improving product quality, worker productivity, \& process improvements. Within these enablers there is no doubt that organizations are willing to apply GT in their organizations. As discussed in the introduction. However according to Udo \& Ehie (1996) only half of those companies adopting GT ever attain successful implementation.

The investigation is then open to explore why organizations couldn't get the full benefits of GT. To explore the reasons many literature has predominantly focused on technical issues (machine order/layout, family part grouping, work flow sequence) using mathematical or simulation methodologies (Singh, 1993; Kazerooni, 1997; Shambu \& Suresh, 2000; Albadawi et al, 2005).it is also confirmed by the early study conducted by Fazakerley (1976) stating that, companies introducing cellular manufacturing have concentrated on such technical issues as classification methods, the design of the workflow sequence and the physical arrangement of machinery for reducing set-up times.

However, Wemmerlov \& Johnson (1997) found that 'people' issues outnumbered 'technical' issues. It is clear from the literature that GT should not be viewed merely as a technical, engineering-dominated problem but as a change process where the people elements play a very important role in the success of GT (Wemmerlov \& Johnson, 1997; Park \& Han, 2002; Chakravorty \& Hales, 2004). But, by comparison, research on the human or social side of GT has been notably lacking (Huber \& Brown, 1991).

It is now accepted that not only the technical factor but also human factors have significant impact in the success of cellular layout. But the impact of human or social side on the success of the GT is a missing field. So this study tries to reduce that gap.

\subsection{Literature Review}

Over the past 15 years there have been various attempts by researchers to develop models for the implementation of GT. Some of these models have built on previous work while others have focused on individual areas of the implementation process. What is missing from the perspective of practitioners is a comprehensive step-by-step guide of the various phases to implement GT. The earlier work had a strong focus on the design phase of manufacturing cells with the major consideration being given to the technical factors (machine order/layout, family part grouping, and work flow sequence). The more recent research has identified the importance of the human factors in GT along with strategic and operational considerations, without providing a comprehensive model 
combining all the various facets (Fraser et al).

In the initial study of GT, Wemmerlov \& Johnson (1997) revealed that manufacturing cells can provide substantial benefits; however, implementing GT is not merely an issue of rearranging the factory layout, but more importantly an issue that involves and effects the organizational and human aspects of the manufacturing firm. Surrounding cell conversions, the authors found that the number of comments about 'soft' (people) issues exceeded the number about 'hard' (technical) ones. As is the case with other studies, the authors found that successful change is more dependent on organizational than technological factors. They also found that 'planning cannot be emphasized enough (and) small, incremental successes should be the basis for larger, integrated cell systems'.

The early empirical work to develop social system factors that supported GT success were conducted by Huber \& Hyer (1985); Huber \& Brown (1991). Huber \& Brown (1991) used socio-technical systems (STS) theories and human resource management practices to provide implementation guidelines for successful implementation of GT. Based on STS theories; they suggest that a complementary match between technical and social systems is needed to ensure optimization of GT implementations.

Based on a review of both existing cell design approaches and socio-technical systems (STS) theory literature, Hyer et al (1999) propose a model of cell system design that considers both technical and social dimensions. In concluding, the authors revealed that there are several key factors significantly affect the successfully introduction of manufacturing cells. These include 'selling' the need for change, general decisions about structure and operation, analysis of social and technical subsystems, cell assignments, detailed design, and implementation. They go to add that in contrast to existing GT literature, these elements paint a far more comprehensive picture of the change process and suggest areas where future research may be targeted.

In an attempt to determine performance obstacles in GT implementation, Park \& Han (2002) found that four factors played an important role: information requirements, training and education of workers, supervision, and teamwork skill. These findings were recently supported by another study of human related issues in GT. In a survey of both operators and managers, Bidanda et al (2005) found that the most important human factors were communication, teamwork, and training.

According to Fraser et al, to obtain the full benefits of GT, successful implementation is a critical factor. Evidence indicates that firms converting to GT often struggle with implementation and achieving results that are less than anticipated. A comprehensive review of implementation literature was undertaken and a multi-phase model developed and tested through a case study. The framework recognizes the 
importance of both technical and human aspects of GT and provides better understanding of the various phases in the implementation process, including the many decisions which need to be considered for each step.

In their study Wemmerlov \& Johnson (1997), found that the most common problem faced by firms in connection with establishment of manufacturing cells were related to cell design, the implementation process, and human issues. The importance of user involvement in effective change is also a frequent theme in the implementation literature. Restructuring the factory to adopt GT should not be viewed merely as a technical, engineering-dominated problem but as a change process where the people element dominates.

Park \& Han (2002), commented that GT implementation is a rich and wide research area where interdisciplinary participation seems fruitful'. In a study of performance obstacles in GT implementation, they found that the major factors were: training and education, information, teamwork skill, supervision, and scheduling.

\section{RESEARCH METHODOLOGY}

The study adopted descriptive survey design which involved quantitative exploratory methods. As the data for this study will be collected at a single point in time, the study was crosssectional in time horizon.

The unit of analysis is the individual level. The target population of the study is large scale garment manufacturing organizations in Sri Lanka. It was further narrowed geographically to the North Western province. The sample consisted with seventy garment factories where GT concept has already been implemented. Judgmental sampling procedure was being applied to select 70 garment manufacturing

organizations in North Western province in Sri Lanka where the GT concept was applied. Then, 70 executives from the sewing department, were selected as value addition for a garment mainly happened in the sewing department. A total of 70 questionnaires together with the covering letter explaining the purpose of the study and the confidential letter were sent through email and personally to the respondents and 60 questionnaires were returned to the researchers with $86 \%$ of response rate.

The structured questionnaire was developed based on the existing literature. The questionnaire was arranged into two sections. The first section was designed to collect data relating to respondents demographic. The second section consists with questions relating to motivational force for applying the GT, benefits of GT, and confronted human relation obstacles in implementing the GT concept in the organization. Collected and compiled data were analyzed using Statistical Package for the Social Science (SPSS). A reliability and validity analyses were performed at the beginning of the analysis. Statistical measures such as mean, standard deviation and percentages were used. Multiple regression analysis was used to measure the 
impact of human barriers/ obstacles on the dependent variable of implementation of GT.

\section{RESULTS AND DISCUSSION}

The demographic characteristics of the respondents are shown in table 1. Accordingly, 28 respondents were female $(47 \%)$, and 32 respondents were male $(53 \%)$. $27 \%$ of the participants' ages were between 20$29,35 \%$ of participants' ages were between $30-39$, and $38 \%$ were over 40 years old. $23 \%$ of participants were bachelors. In terms of working experience, $42 \%$ of the respondents have less than 5 years working experience, $52 \%$ have 5-10 years, and $6 \%$ have more than 10 years working experience.

Table 1. Demographic

\section{Characteristics of Respondents}

\begin{tabular}{|l|l|l|l|}
\hline Demographics & & N & $\%$ \\
\hline Gender & Female & 28 & 47 \\
\hline & Male & 32 & 53 \\
\hline Age & $20-29$ & 16 & 27 \\
\hline & $30-39$ & 21 & 35 \\
\hline & Over 40 & 23 & 38 \\
\hline Marital status & Not married & 14 & 23 \\
\hline & Married & 46 & 77 \\
\hline $\begin{array}{l}\text { Working } \\
\text { experience }\end{array}$ & $\begin{array}{l}\text { Less than } 5 \\
\text { years }\end{array}$ & 25 & 42 \\
\hline & $\begin{array}{l}\text { Between 5 and } \\
10 \text { years }\end{array}$ & 31 & 52 \\
\hline & Over 10 years & 9 & 6 \\
\hline & \multicolumn{2}{|l}{} \\
\hline
\end{tabular}

\section{Preliminary Analyses}

It is essential to calculate the validity and reliability of measures used in the study before analyzing the data. The Cronbach Alpha value is considered as a measure of scale reliability. Cronbach's alpha value of 0.869 indicating excellent level of reliability according to Gliem \& Gliem (2003).

Univariate and bivariate normality was tested by using KMO test and Bartlett's Test of Sphericity. Accordingly, KMO measure for all the constructs is above 0.6 indicating the sample is adequate. Bartlett's Test of Sphericity is significant $(>0.05)$ for all construct which indicating sufficient correlation exists among items to proceed.

\section{Reasons for Applying GT}

In order to understand the main reasons for introducing GT, the respondents were asked to specify the different production problems faced by their organizations. According to the respondents point of view high inventory storage and high lead time is the severe production problem which caused to implement the GT in garment factories. It is also important to point out that quality problems and as well as worker dissatisfaction is also play as a motivational force in applying GT system. 


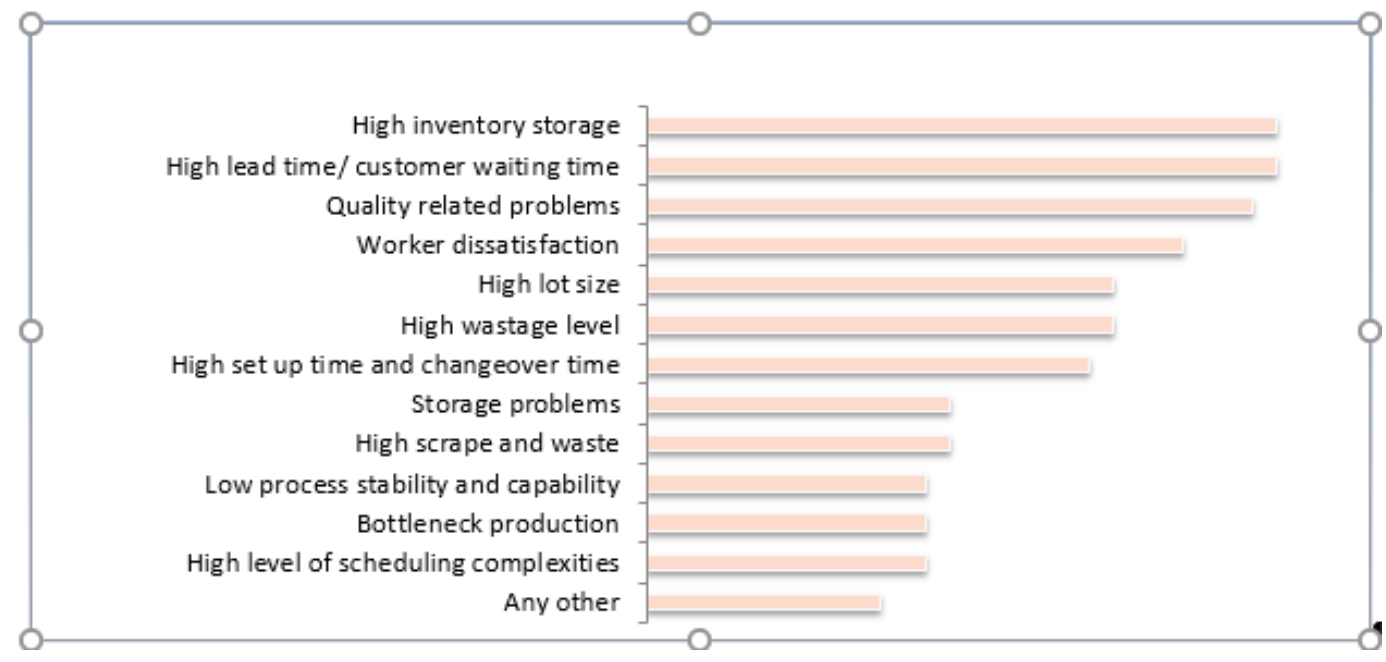

Figure 1. Reasons for Applying GT

\section{Perceived Benefits of GT}

In the survey instrument, the respondents were asked to rate their perception on the benefits of implementing GT. The reasons and their relative importance were considered. Multiple benefits have been identified as critical because the average respondent view is not less than 4. According to analysis the main benefits gained from implementing the GT are increased worker productivity, worker skills and flexibility has increased, product quality has increased, on time delivery, decreased lead time, reduced inventory level, reduced set up time and throughput time, reduction of production and quality control cost.

\section{Table 2. Benefits Gained from GT}

\begin{tabular}{|c|c|c|c|c|c|c|c|}
\hline Benefits of GT & 芯 & 昂 & $\begin{array}{l}\text { 总 } \\
\text { 号 } \\
\text { 品 }\end{array}$ & 离 & $\begin{array}{l}\text { 氶 } \\
\text { 。ㅇ }\end{array}$ & 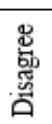 & 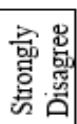 \\
\hline Worker productivity has increased & 4.4 & 0.41 & 41 & 54 & 5 & - & - \\
\hline Workers" skills and flexibility has increased & 4.6 & 0.38 & 45 & 38 & 17 & - & - \\
\hline Improve the quality of the product & 4.0 & 0.57 & 32 & 59 & 9 & - & - \\
\hline Increase customer satisfaction & 3.5 & 0.52 & 10 & 58 & 32 & - & - \\
\hline On time delivery reduce overdue orders & 4.3 & 0.37 & 42 & 48 & 10 & - & - \\
\hline Reduce the level of inventory & 4.6 & 0.31 & 48 & 35 & 17 & - & - \\
\hline Reduce lead time & 4.1 & 0.57 & 43 & 50 & 7 & - & - \\
\hline Reduce lot size & 3.9 & 0.53 & 22 & 37 & 32 & 9 & - \\
\hline Improve production process stability and capability & 3.9 & 0.47 & 33 & 32 & 35 & - & - \\
\hline Reduce defect rate, rework and warranty work & 3.6 & 0.69 & 25 & 42 & 23 & 10 & - \\
\hline Reduce space for storage and product line & 3.8 & 0.78 & 21 & 33 & 37 & 9 & - \\
\hline Reduce set up time & 4.1 & 0.56 & 24 & 42 & 27 & 7 & - \\
\hline Reduce time for new product development & 3.4 & 0.51 & 18 & 25 & 33 & 24 & - \\
\hline Reduce time for new process launch & 3.6 & 0.51 & 22 & 31 & 42 & 5 & - \\
\hline Reduce scrape waste & 3.5 & 0.52 & 21 & 27 & 30 & 22 & - \\
\hline Reduce throughput time & 4.3 & 0.37 & 19 & 48 & 25 & 8 & - \\
\hline Reduce production and quality control cost & 4.4 & 0.47 & 28 & 35 & 9 & - & - \\
\hline Improve resource utilization & 4.3 & 0.27 & 17 & 47 & 27 & 9 & - \\
\hline Production flow become more visible & 3.7 & 0.72 & 10 & 29 & 45 & 16 & - \\
\hline
\end{tabular}




\section{Human Related Issues in Implementing GT}

Table 3. Human Related Issues in Implementing GT

\begin{tabular}{|c|c|c|c|c|c|}
\hline Barriers / obstacles & 营 & 沓 & 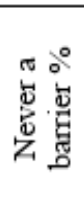 & 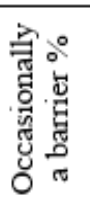 & 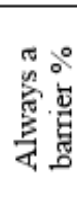 \\
\hline Workers' resistance to change & 1.2 & 0.31 & & 20 & 80 \\
\hline Lack of knowledge about GT principles and techniques & 1.3 & 0.14 & 10 & 25 & 65 \\
\hline Lack of training and education in the use of GT technique & 1.3 & 0.11 & & 30 & 70 \\
\hline Fear of losing job & 1.9 & 0.45 & 20 & 30 & 50 \\
\hline Influence of trade unions & 2.6 & 0.22 & 60 & 40 & \\
\hline Communication barriers & 2.2 & 0.45 & 30 & 30 & 40 \\
\hline Lack of involvement from top management & 1.4 & 0.23 & & 30 & 70 \\
\hline Managers' resistance & 2.3 & 0.31 & 40 & 50 & 10 \\
\hline
\end{tabular}

The major Barriers / obstacles in applying GT are presented in the above table. In the questionnaire respondents were asked to degree the barriers faced by them when applying GT technique. The responses were evaluated based on three point Likert scale (never a barrier (3), occasionally a barrier (2) and always a barrier (1)). The workers' resistance is the most significant barrier when applying GT system $($ mean $=1.2$ and $\mathrm{SD}=0.31)$. Similar results were found in another study conducted by Dixit \& Gupta in 2013. According to authors workers' resistance is the prominent barrier for the implementation of GT system in the Indian firm. Lack of knowledge about GT principles and techniques and as well as lack of training and education in the use of GT techniques is also identified as major obstacles in applying GT system.

\section{Hierarchical Multiple Regression Analysis}

In order to test the effect of human related barriers on the implementation of GT, multiple regression analysis was performed.

Table 4. Model Summary

\begin{tabular}{|l|l|l|l|l|l|}
\hline Model & R & R Square & Adjusted R Square & $\begin{array}{l}\text { Std. Error of the } \\
\text { Estimate }\end{array}$ & Durbin-Watson \\
\hline 1 & $.79^{\mathrm{a}}$ & .62 & .61 & .03157 & 1.87 \\
\hline
\end{tabular}

According to the model summary table, multiple correlation is 0.79 which indicates that human related issues are having strong joint association with the implementation of GT. Coefficient of determination is 0.62 , indicating that $62 \%$ of GT implementation has been explained by the multiple regression model. As the value exceeds $60 \%$, it is concluded that the model is well fitted. DurbinWatson test statistics is 1.87 which falls in between $1.5-2.5$, signifying the fact that the residuals of the regression model are independent and tend to be appropriate. 
Table 5. F- test Statistics

\begin{tabular}{|l|l|l|l|l|l|l|}
\hline \multicolumn{2}{|l|}{ Model } & Sum of Squares & Dff & Mean Square & F & Sig. \\
\hline \multirow{2}{*}{1} & Regression & 57.245 & 4 & 13.811 & 186.9 & $.000^{\mathrm{b}}$ \\
\cline { 2 - 8 } & Residual & 20.035 & 351 & .001 & & \\
\cline { 2 - 7 } & Total & 87.280 & 394 & & & \\
\hline
\end{tabular}

In relation to the regression ANOVA result, probability of $\mathrm{F}$ test statistics happened to be highly significant as the $\mathrm{P}$ value is 0.00 , interpreting that the all independent variables jointly influence on the dependent variable of implementation of GT.

\section{Table 6. Coefficients}

\begin{tabular}{|c|c|c|c|c|c|c|c|}
\hline \multirow{2}{*}{\multicolumn{2}{|c|}{ Model }} & \multicolumn{2}{|c|}{$\begin{array}{l}\text { Unstandardized } \\
\text { Coefficients }\end{array}$} & $\begin{array}{l}\text { Standardized } \\
\text { Coefficients }\end{array}$ & \multirow[t]{2}{*}{$\mathrm{T}$} & \multirow[t]{2}{*}{ Sig. } & \multirow{2}{*}{$\begin{array}{l}\text { Collinearity } \\
\text { Statistics } \\
\text { VIF }\end{array}$} \\
\hline & & B & Std. Error & Beta & & & \\
\hline \multirow{5}{*}{1} & (Constant) & 60.46 & .070 & & 2.2 & .03 & 1.1 \\
\hline & Workers' resistance & -.58 & .107 & -.64 & -1.4 & .00 & 2.4 \\
\hline & Lack of knowledge & -.51 & .075 & -.58 & -6.4 & .00 & 1.9 \\
\hline & Lack of training & -.46 & .068 & -.50 & -26.8 & .01 & 3.2 \\
\hline & Fear of losing job & -.15 & .018 & -.21 & -12.4 & .04 & 1.4 \\
\hline & $\begin{array}{l}\text { Influence of trade } \\
\text { unions }\end{array}$ & -.32 & .13 & -.39 & -.55 & .37 & 4.2 \\
\hline & $\begin{array}{l}\text { Communication } \\
\text { barriers }\end{array}$ & -.22 & .10 & -.28 & -.88 & .47 & 3.2 \\
\hline & $\begin{array}{l}\text { Lack of involvement } \\
\text { from top management }\end{array}$ & -.39 & .26 & -.43 & -12.4 & .00 & 1.8 \\
\hline & Managers' resistance & -.12 & .25 & -.51 & -16.6 & .01 & 2.4 \\
\hline
\end{tabular}

The results of the multiple regression analysis further verifies the fact that seven out of nine independent variables (except influence of trade unions and communication barriers) have negative influence on the implementation of GT. Worker resistance to change found to be having the greatest impact which is closely followed by lack of knowledge and trading. In addition to that fear of losing jobs, lack of involvement from top management and managers' resistance happened to be significant since all are below 0.05 significant level. In contrast, influence of trade unions and communication barriers are individually insignificant as the $\mathrm{P}$ values are higher than 0.05 . Hence, these factors are removed from the model. Additionally, all the variance influencing factors (VIF) are less than 10 , indicating data set is free from multicollinearity problem and model is appropriate. 


\section{CONCLUSION}

When applying GT, organizations need to provide keen attention on human resource issues such as employee resistance to change, knowledge and training of GT technique, top management involvement to get the fullest benefits of GT. As garment industry is more people involved process, it is critical to obtain the positive commitment of the people in the implementation of GT. The most effective way of obtaining positive contribution from the people through education and training.

Change disrupts the status quo and often leads to stress, discomfort, and for some even dislocation. These conditions motivate people to resist change. Attempts to implement change are more likely to be successful if leaders understand the reasons behind employees' resistance to change. According to Lussier \& Achua (2003) the most common reasons why people resist change are; threat to one's self interest, Uncertainty, lack of confidence that change will succeed, lack of conviction that change is necessary, distrust of leadership, threat to personal values, fear of being manipulated. So, it is recommended to minimize employee resistance by applying several techniques such as; effective communication before, during and after the application of GT, effective training and development, empowering employees, employee involvement programmes, establishing supportive reward structure, and as well as upgrading top managers involvement.
Effective communication before, during, and after the change implementation process will prevent misunderstandings, false rumors and conflicts. It is important that those responsible for implementing change not hear about it from second hand sources (Lussier \& Achua,2003).

Most organizations will begin the GT conversion with a large pool of employees who are not attuned to group work, and initial training must be geared to convince them of the general effectiveness of group problem solving (Huber \& Brown, 1991). Following that, training in group interaction skills may be necessary. Components of this training may include oral communication skills, listening, joint problem solving, and negotiation. According to the point of Schuler and Huber (1990) an organization may need to provide cell members with training in basic skills, interpersonal skills, and conceptual/integrative skills. Interpretation of statistical process control charts, review of documents, and report writing, are likely to make this training essential. Interpersonal and conceptual/intergrative skills also may help employees to solve problems, listen to coworkers, develop intra- and inter-cell coordination mechanisms and interpret data, all of which will enable them to meet the new requirements of the GT work environment. As well as allow time after training for the team members to bond with one another and form team skills.

Reward Structures. Reward structures address the ways in which people are compensated for work. Reward 
systems which promote teamwork will be preferred in GT environments, and it will be important for the application of these systems to be consistent throughout the plant. Inconsistencies can create tremendous conflict between interdependent employees or work units. Two major compensation system options likely to promote teamwork in GT environments are gain-sharing and profit sharing.

Strong support from senior management is crucial to ensure that they support the efforts to implement the environment that is desirable for GT rather than undermine it. This requires careful attention on team members' problems, allocate the adequate resources and provide training opportunities for the team members to perform their task effectively and as well as to create the organizational culture where GT can grow and success.

\section{REFERENCES}

Anbumalar, V. and Raja Chandra Sekar (2015), Methods For Solving Cell Formation, Static Layout And Dynamic Layout Cellular Manufacturing System Problems: A Review, Asian Journal of Science and Technology, 2015

Esmaeilian G. R. and Maryam Hamedi (2012),A Survey on Development of Virtual Cellular Manufacturing Systems and Related Issues, Paper presented at the International Conference on Industrial Engineering and Operations Management Istanbul, Turkey 2012
Huber, V.L., and Hyer, N.L., 1985, The Human Factor in Cellular Manufacturing. Journal of Operations Management 5 (2), 213-228

Huber, V. L. and Brown, K. A., 1991, Human resource issues in cellular manufacturing: a sociotechnical analysis. Journal of Operations Management, 10, 138 \pm 159 .

Hyer, N. L. and Brown, K. A., 1999, The discipline of real cells. Journal of Operations Management, 17(5), 557 \pm 574

Kumar A.A.S., Anbumalar, V., Ganesh, N.B., Mayandy, R. (2014). Implementation of Cellular Manufacturing Systems in Garments Industry: A Case study. International Journal of Innovative Research in Science, Engineering and Technology, 3(Special Issue 3), 1298-1292.

Lanarolle, G., and Ratnayake, V. (2014). Cellular Manufacturing and Teamwork Concepts in Garment Manufacturing. Journal of Business and Management, 16 (6), 81-93.

Lussier, R. N., \& Achua, C. F. (2004). Leadership: Theory, application, skill development (2nd ed.). Sydney: Thompson.

Pullen, R. D., 1976, A survey of cellular manufacturing cells. The Production Engineer, 55, $451 \pm 454$. 
Shambu, G., \& Suresh, N. C. (2000). Performance of hybrid cellular manufacturing systems: A computer simulation investigation. European Journal of Operational Research, 120, 436458.

Singh, N., 1993, Design of cellular manufacturing systems: an invited review. European Journal of Operational Research, 69, $284 \pm 291$.

Udo, G.J., Ehie, I.C. (1996) "Advanced manufacturing technologies: Determinants of implementation success ", International Journal of Operations \& Production Management, Vol. 16 Iss: 12, pp.6 $-26$

Wemmerloïv, U. and Hyer, N.L., 1989, Cellular manufacturing in the US industry: a survey of users. International Journal of Production Research, 27, $1511 \pm 1530$.
Wemmerlov U., Hyer N.L. (1999), Cellular manufacturing in the U.S. industries: A survey of users; International Journal of ProductionResearch 27(9); 15111530

Wemmerlov U., Johnson D.J. (1997), Cellular manufacturing at 46 user plants:

Implementationexperiences and performance improvements; International Journal of Production Research 35; 29-49.

Wemmerlo"v, U., D. J. Johnson. 2000. Empirical findings on manufacturing cell design. International Journal of Production Research 38(3) 481507 